\title{
BRIEF REPPORT
}

\section{Improved RT-PCR SARS-Cov2 results interpretation by indirect determination of cut-off cycle threshold value.}

\author{
Khelil Mohamed Mokhtar \\ Pasteur institute of Algeria, department of immunology, Annex of M'sila, Algeria.
}

\section{Corresponding author.}

E-mail address: kh.immuno@gmail.com

Phone: +213781032119

\begin{abstract}
Clinical laboratories of the developing world are overwhelmed with RT-PCR SARS-Cov2 testing demands. It is of paramount importance that each clinical laboratory use an appropriate cut-off value in the interpretation of SARS-Cov2 real-time RT-PCR results, which is specific to their laboratory performances as ISO 15189 recommendations stipulate. We applied an indirect statistical method to a large mixed data set of $\mathrm{Ct}$ values (ORF1ab and $\mathrm{N}$ ) to estimate cut-off $\mathrm{Ct}$ value ( 32 cycles).we conclude that the use of indirect statistical approaches to estimate cut-off value in the interpretation of SARS-Cov2 real-time RT-PCR results may improve differential diagnosis of COVID-19 cases with low risk of infectivity, and may help to better estimates of the burden of COVID-19 disease.
\end{abstract}

\section{Keywords:}

SARS-CoV-2; Indirect reference limits; RT- PCR; Cut-off cycle threshold

\section{Dear editor;}

Clinical laboratories played a key role in controlling spread of SARS-COV2 virus by rapid diagnosis of COVID-19 cases which aid in rapid isolation of confirmed cases and close contacts, with social movement constrain (1). On 27 May 2020, WHO provided updated recommendations on the criteria for discharging patients from isolation. Patients were discharged 13 days after symptom onset for symptomatic cases and 10 days after positive test for SARS-Co2 for asymptomatic (2). These recommendations were based on evidences showing the low probability of virus culture in upper respiratory samples after 9-10 days after symptom onset (3-4). Only a few studies have studied how RT-PCR detection (i.e.: Cut-off cycle threshold "Ct") relates to cultivable virus (4-5). However there was a general agreement that $\mathrm{Ct}$ values were strongly associated with the ability to recover infectious SARS-COV2 virus .Furthermore a cycle threshold cut-off 33-35 was associated with low infectivity. Clinical laboratories often use Ct cutoff provided by the RT-PCR kit manufacturers which are between 37 and 40 cycles. Ideally, each clinical laboratory should perform its own correlation between culture results and viral RNA load from patients' samples, but the process is not widely available and require biosafety level 3 
facilities. The aim of this study was to estimate a local cut-off value for SARS-Cov2 viral load by data-mining using intra-laboratory $\mathrm{Ct}$ values, which can be used as a surrogate for infectiousness. We started from the observation that distributions of ORF1ab and $\mathrm{N} \mathrm{Ct}$ values in screening cases are typically bimodal. We hypothesized that the lower $\mathrm{Ct}$ value peak corresponds to patients with high infectivity, and the higher $\mathrm{Ct}$ value peak corresponds to patients for with low infectivity. We modelled the ORF1ab and $\mathrm{N} \mathrm{Ct}$ values bimodal distributions with a finite-mixture model -alias maximum likelihood model- and estimated local Ct Cut-off values associated with SARS-Cov2 infectivity risk.

The dataset used in this study were generated from a retrospective, outpatients based COVID-19 results, in INSTITUT PASTEUR OF M'SILA, ALGERIA. Only screening results were included. SARS-CoV-2 RNA positivity was assessed by real-time reverse transcription-PCR targeting the ORF1 ab and $\mathrm{N}$ genes, as previously described (7). We assumed that high and low infectivity populations follow a Gaussian distribution. The bimodal distribution of $\mathrm{Ct}$ values of ORF1 an and $\mathrm{N}$ was modelled by the finite mixture model using an open source software package (mixtool) in the $\mathrm{R}$ programming language (8-9).For each distribution, parameters $\lambda, \mu 1, \sigma 1, \mu 2$, $\sigma 2$ were estimated by the maximum likelihood approach using the expectation maximization (EM) algorithm, the confidence intervals were calculated using the formula: $95 \% \mathrm{CI}=+/-2.81 * \sigma / \sqrt{ } n$ as proposed by Boyd (10).

From the $13^{\text {th }}$ July to the 13 th October 2020, a total of 3076 nasopharyngeal (NP) samples from outpatients (1230 female and 1846 male) were collected and examined for SARS-Cov-2 RNA presence. The mean (median) age of female was 54 years (55 years) and for male was 55 years (55 years). $2444 \mathrm{Ct}$ values ( $\mathrm{N}$ and ORFlab gene) of BIOGERM ${ }^{\mathrm{TM}}$ RT-PCR kit were collected and analysed. From $2444 \mathrm{Ct}$ values there were only 41 repeats, medians of $\mathrm{Ct}$ were 35.44 and 35.25 for ORF1ab and $\mathrm{N}$ gene respectively.

The finite mixture model was applied to fit two Gaussian distributions in the mixed data set $(\mathrm{Ct}$ values of ORF1ab and $\mathrm{N}=<45$ ) (Figure1.A and B).For ORF1ab datasets, the $2.5^{\text {th }}$ percentile of the right curve (in green) and the $97.5^{\text {th }}$ percentile of the left curve (in red) were 29.2 (95\%CI: 29.01-29.5) and 32.3 (95\%CI: 32-32.6) respectively. For $\mathrm{N}$ dataset, the 2.5th percentile of the right curve (in green) and the 97.5th percentile of the left curve (in red) were 27.9 (95\% CI: (27.6-28.1) and 30.7 (95\%CI: 30.5 - 30.9) respectively. Using the $2.5^{\text {th }}$ percentiles $(\sim 29)$ and the 97.th percentiles $(\sim 32)$ as cut-offs, the adjusted COVID-19 detection rates reduced significantly from $89 \%$ to $36 \%$ and $52 \%$ respectively.

To the best of our knowledge, cut-off cycle threshold value of SARS-cov2 RT-PCR has not been estimated previously by indirect statistical procedures .In this study, we propose an indirect approach to distinguish COVID-19 cases with high likelihood of infectiousness versus cases with low likelihood of infectiousness. Our method apply the finite-mixture model to local retrospectives dataset of ORF1 ab and $\mathrm{N} \mathrm{Ct}$ values. It was founded on the observation that the distribution of $\mathrm{Ct}$ values for ORF1ab and $\mathrm{N}$ is bimodal, and the assumption that the central part of the total distribution represents the low infectivity population (11). Our results show that the $97.5^{\text {th }}$ percentiles of the lower peaks (ORF1ab and $\mathrm{N}$ ) which is ( 32 cycles) may represents the maximum diagnostic efficiency cut-off. Our findings have been demonstrated by two ways: (1) our model-based cut-off was different but close to that obtained by La Scola et al (33-34 cycles) 
and Singanayagam et al (35 cycles). This was expected, due to the differences in laboratory practices (i.e.; different sampling technique and medium, RNA extraction methods, method sensitivity).(2) After applying the estimated cut-off $(\mathrm{Ct} \leq 32)$ to our dataset, the proportion of COVID-19 positive cases decreased by $37 \%$ compared to $20 \%$ ( $\mathrm{Ct} \leq 35$ ).

We conclude that indirect statistical methods may allow the estimation of cut-off cycle threshold value of SARS-COV2 RT-PCR from a large dataset stored in laboratory information system. We suggest that each clinical laboratory conducting routine diagnosis of COVID-19, should determine its own cut-off depending on its own laboratory practices and analytical method performances. We argue that it may be necessary for some regional laboratories with similar patient's characteristics using the same pre-analytical and analytical procedures to form a common data pool and calculate common cut-off $\mathrm{Ct}$ value, which could aid to improve our understanding of the burden of COVID-19 disease.

\section{REFERENCES}

(1) Ioanna Smyrlaki et al. Massive and rapid COVID-19 testing is feasible by extraction free SARSCoV-2 RT-qPCR. BioRxiv. Available at : https://doi.org/10.1101/2020.04.17.20067348.

(2) WHO. Scientific Brief: Criteria for releasing COVID-19 patients from isolation. Available at : https://www.who.int/news-room/commentaries/detail/criteria-for-releasing-covid-19-patientsfrom-isolation

(3) Wolfel R, Corman VM, Guggemos W, et al. Virological assessment of hospitalized patients with COVID-19. Nature. 2020; 581: 465-69.

(4) World Health Organization. Laboratory biosafety guidance related to coronavirus disease (COVID-19)(https://www.who.int/publications/i/item/laboratory-biosafety-guidance-related-tocoronavirus-disease-(covid-19, 13 May 2020)

(5) La Scola Bernard et al. Viral RNA load as determined by cell culture as a management tool for discharge of SARS-CoV-2 patients from infectious disease wards. European Journal of Clinical Microbiology \& Infectious Diseases (2020) 39:1059-1061.

(6) Singanayagam Anika, Patel Monika, Charlett Andre, Lopez Bernal Jamie, Saliba Vanessa, Ellis Joanna , Ladhani Shamez , Zambon Maria , Gopal Robin . Duration of infectiousness and correlation with RT-PCR cycle threshold values in cases of COVID-19, England, January to May 2020. Euro Surveill. 2020; 25(32):pii=2001483. Available at : https://doi.org/10.2807/15607917.ES.2020.25.32.2001483.

(7) Khelil Mohamed mokhtar. Improved COVID-19 testing by extraction free SARS-Cov-2 RT-PCR.medRxive. Available at : https://doi.org/10.1101/2020.08.10.20171512.

(8) R Core Team (2013). R: A language and environment for statistical computing. R Foundation for Statistical Computing, Vienna, Austria. URL http: //www.R-project.org/.

(9) Benaglia T, Chauveau D, Hunter DR, Young D (2009). "mixtools: An R Package for Analyzing Finite Mixture Models." Journal of Statistical Software, 32(6), 1-29. http://www.jstatsoft.org/v32/i06/. 
medRxiv preprint doi: https://doi.org/10.1101/2020.11.20.20235390; this version posted November 23, 2020. The copyright holder for this preprint (which was not certified by peer review) is the author/funder, who has granted medRxiv a license to display the preprint in perpetuity.

It is made available under a CC-BY-NC 4.0 International license .

(10) Ichihara K, Boyd JC, IFCC Committee on Reference Intervals and Decision Limits (CRIDL). An appraisal of statistical procedures used in derivation of reference intervals. Clin Chem Lab Med 2010;48:1537-51.

(11) Jones GR, Haeckel R, Loh TP, Sikaris K, Streichert T, Katayev A, et al; IFCC Committee on Reference Intervals and Decision Limits. Indirect methods for reference interval determination - review and recommendations. Clin Chem Lab Med 2018; 57:20-9. 
medRxiv preprint doi: https://doi.org/10.1101/2020.11.20.20235390; this version posted November 23, 2020. The copyright holder for this preprint (which was not certified by peer review) is the author/funder, who has granted medRxiv a license to display the preprint in perpetuity.

It is made available under a CC-BY-NC 4.0 International license .
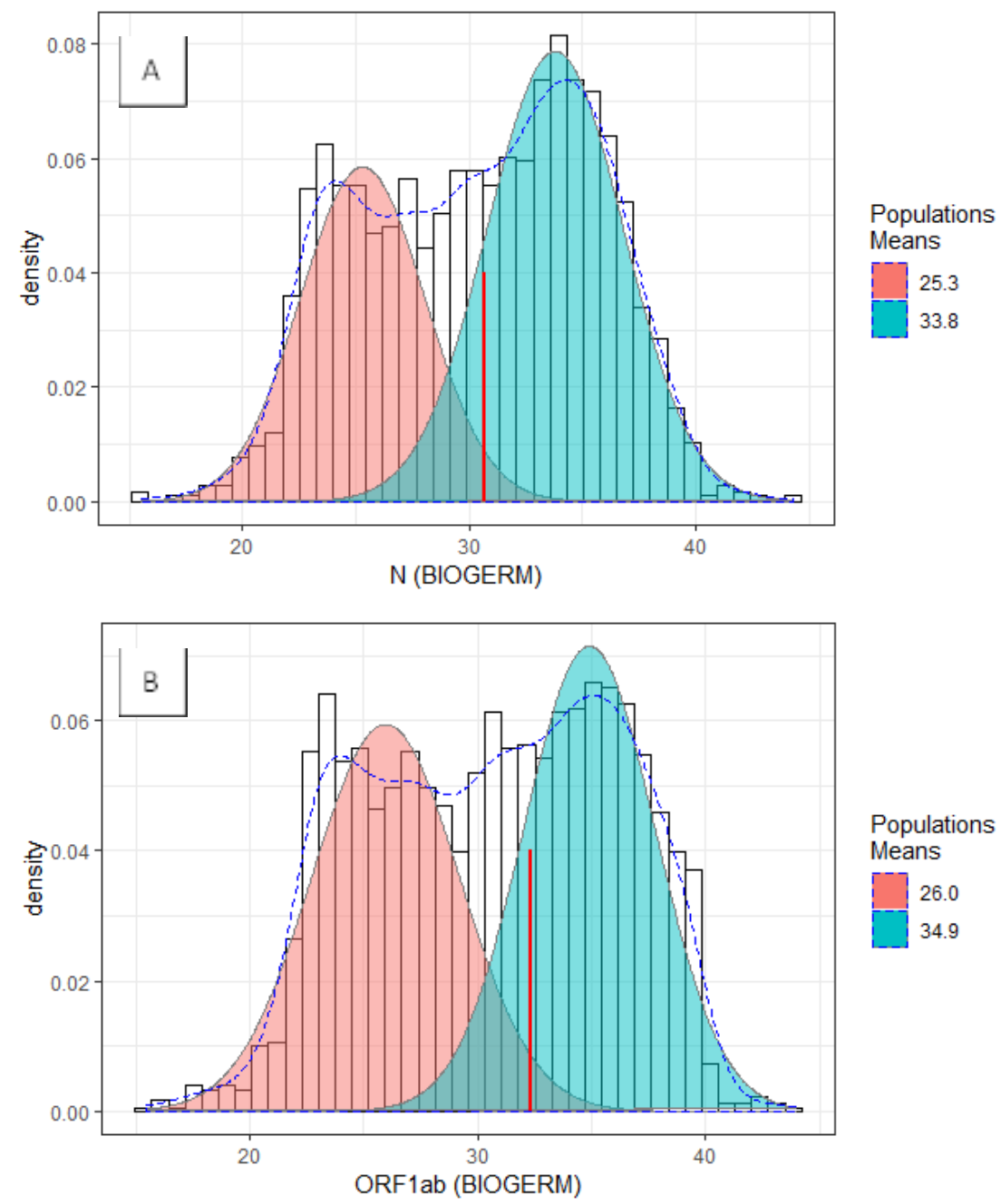

Populations

Means

26.0

34.9

Figure1. Maximum likelihood modeling of $\mathrm{Ct}$ values distributions for $\mathrm{N}$ gene (Figure $2 \mathrm{~A}$ ) and ORF1ab gene (BIOGERM ${ }^{\mathrm{TM}}$ ) (Figure $2 \mathrm{~B}$ ). The curves in the left (in red) represent high infectiousness population and the curves in the right (in green) represent low infectiousness population. Dashed blue curves display the mixed population. Red vertical segments represent the Cut-off Cycle thresholds. 